\title{
DSM 5 through several lenses: how eating disorders can look different
}

\author{
Anthea Fursland ${ }^{1 *}$, David Erceg-Hurn', Susan Byrne ${ }^{2}$ \\ From 2015 ANZAED Conference: Riding the Waves to Recovery \\ Surfers Paradise, Australia. 21-22 August 2015
}

The Eating Disorder Examination (EDE), a structured diagnostic interview, is the 'gold standard' for diagnosing eating disorders (EDs). There are well established algorithms for DSM-IV diagnosis but not for DSM-5. The various algorithms proposed for DSM-5 differ in terms of their use of the EDE to operationalise diagnostic criteria such as low weight, episodes of binge eating, and compensatory behaviours to prevent weight gain. We compared four DSM-5 EDE diagnostic algorithms, to evaluate the extent to which the choice of algorithm affects the diagnosis given to a patient. Participants were over 400 patients referred to a specialist West Australian ED outpatient clinic. Clinical psychologists administered the EDE to each patient and these EDE scores were analysed using four different algorithms. We found that, for a significant minority of patients, the diagnosis derived from the EDE changed depending on what diagnostic algorithm was used. The results indicate that competing algorithms for diagnosing DSM-5 EDs using the EDE are not interchangeable, and that the choice of algorithm has a practical impact on which diagnosis is given. The significant implications of these findings for research and clinical practice will be discussed.

\section{Authors' details}

${ }^{1}$ Centre for Clinical Interventions, Perth, Australia. ${ }^{2}$ University of Western

Australia, Perth, Australia.

Published: 23 November 2015

doi:10.1186/2050-2974-3-S1-053

Cite this article as: Fursland et al.: DSM 5 through several lenses: how eating disorders can look different. Journal of Eating Disorders 20153 (Suppl 1):053.

\footnotetext{
* Correspondence: anthea.fursland@health.wa.gov.au

${ }^{1}$ Centre for Clinical Interventions, Perth, Australia

Full list of author information is available at the end of the article
}

Submit your next manuscript to BioMed Central and take full advantage of:

- Convenient online submission

- Thorough peer review

- No space constraints or color figure charges

- Immediate publication on acceptance

- Inclusion in PubMed, CAS, Scopus and Google Scholar

- Research which is freely available for redistribution
C Biomed Central
C Biomed Central

(c) 2015 Fursland et al. This is an Open Access article distributed under the terms of the Creative Commons Attribution License (http:// creativecommons.org/licenses/by/4.0), which permits unrestricted use, distribution, and reproduction in any medium, provided the original work is properly cited. The Creative Commons Public Domain Dedication waiver (http://creativecommons.org/publicdomain/ zero/1.0/) applies to the data made available in this article, unless otherwise stated. 